\title{
Accounting
}

\section{Supply chain performance, profitability and Liquidity: An analytical study of Indian pharmaceutical sector}

\author{
Anis Alia ${ }^{\text {* }}$
}

${ }^{a}$ College of Business Administration, Prince Sattam Bin Abdulaziz University, Al kharj-11942, Saudi Arabia

\begin{tabular}{l}
\hline C H R O N I C L E \\
\hline Article history: \\
Received: November 26, 2020 \\
Received in revised format: \\
January 302021 \\
Accepted: March 18, 2021 \\
Available online: \\
March 18, 2021 \\
\hline Keywords: \\
Supply chain performance (SCP) \\
Liquidity \\
Profitability \\
Indian pharmaceutical \\
Cash Conversion Cycle (CCC)
\end{tabular}

\section{Introduction}

The SCP defines the operational velocity and is measured by the manufacturing efficiency (inventory days), ability of recovery from the debtors (accounts receivables days), and payment to creditors (account payables days). Generally, the SCP enhances the frequency of production of the business and affects the profitability and the liquidity due the enhancement of the level of operational activities. Johnson et al. (2011) found the positive impact of SCM on the firms' performance. Profitability is the relative measurement and explains the earning capacity of the business while liquidity refers to the short term paying ability of the business organization or how much a firm is able to pay-out its short-term liabilities. Profit is the essence or results of business activities of the business organization while profitability measures the relative performance or operational efficiency

\footnotetext{
* Corresponding author.

E-mail address: ah.ali@psau.edu.sa (A. Ali)
} 
and facilitates comparative analysis among similar business organizations. Normally, it is assumed that the extreme liquidity restricts or lowers the profits and blockage of cash or liquid assets in non-economic avenues while low liquidity is the hindrance in the normal course of action of making payments of the dues or liabilities. Ben-Caleb et al. (2013) explained that the polar extreme (highest and lowest) of the liquidity is harmful to the running of the operational activities smoothly while liquidity has a low degree of influence on profitability. So, both the situations avoided and balance is preferred between liquidity and profitability to run the activities smoothly and to make the payments of the dues on time. In the Indian pharmaceutical industry, the profit is affected by the size of the firm while the size of the firm is to be determined by the three determinants i.e. Sales, Total resources, and working capital (Ali, 2020a ). The working capital (WC) is the excess of current assets on current liabilities while the working capital ratio is the ratio of current assets and current liabilities which is the current ratio (CR). So, the level of current ratio also defines the size of the business, and the higher level CR indicates the liquidity. In Indian Pharmaceutical companies, the size of the firm affects profits not profitability (Ali, 2020b). In a business organization, WC is the significant size determinant that governs the sales and utilizes the total assets or fixed assets to operate the business activities for the attainment of the ultimate objectives. The WC of the business organization can be bifurcated into two i.e. permanent and seasonal. The permanent WC capital is required throughout the tenure while the seasonal WC is required only for a particular period in a year. Liquidity's point of view, there is only consideration of cash or cash equivalent that is the ingredient of the current assets. So, the current ratio (CR) and the weightage of the cash or cash equivalent in the current assets is also a factor that affects the smoothness of the operational activities and leads towards the profits and finally improves profitability. Pushparaj Kulkarni et al. (2019) observed a significant negative relationship between solvency or liquidity and profitability in the Indian pharmaceutical industry. In the Indian pharmaceutical sector, the firms are either having the liquidity in paying their short term liabilities or enjoying the profitability by lowering the paying ability of the firms. Farhan et al. (2019) found that the third factor i.e. corporate governance affects the relationship between liquidity and profitability of Indian pharmaceutical companies. It refers that the profitability and liquidity of the business organization are highly governed by efficient corporate governance more than the mutual governance of profitability and liquidity. Panigrahi et al. (2018) found a negative relationship between liquidity and profitability in pharmaceutical companies. They explained that all profitable business organizations need not necessarily suffer from liquidity or all liquid businesses need not have low profitability. Indirectly, they denied the clear relationship between the profitability and liquidity in Indian pharmaceutical companies. Further, Panigrahi et al. (2019) studied that the relation of profitability and liquidity varies industry to industry and the profitability and liquidity relation of a particular industry need not be the same in other countries. Srivastva (2017) observed that the Indian pharmaceutical industry's profitability is satisfactory but could not relate to the liquidity or paying ability of the firms Mohanty et al. (2018) carried out a study of the relationship of profitability and liquidity on SMEs in India and found significant relation. The impact of liquidity on profitability is negative in SMEs in India. Sinha et al. (2017) studied the liquidity of the Cipla and Ranbaxy pharmaceutical companies of India and concluded that the long term solvency is stronger than the liquidity in both companies. The present study considers the impact and relationship of liquidity and profitability and additionally measures the average relational movement of profitability and liquidity, and co-movement of relational productivity of liquidity and profitability and liquidity relationship and tries to get the relational impact of liquidity on profitability and facilitates the suggestions to the Indian pharmaceutical industry to enhance the profitability.

\section{Literature Review}

Alagathurai (2013) found a positive and significant relationship between liquidity and profitability of trading companies in Sri Lanka. The profitability of a business organization affects the liquidity and liquidity also facilitates the smooth operation of business activities and enhances profits and profitability. Sinha et al. (2016) found in their study that the efficient liquidity or cash management of the business organization affects the profitability positively. The liquidity of the business should be optimum so that it can pay off its short-term liabilities and avoid to blockade in the neutral options. Kumar et al. (2016) observed in their study that the ingredients of working capital (current assets and current liabilities) and their efficient management positively affect the profitability and maintain the paying ability of the business organization. But, Priya et al. (2013) found a negative relationship between liquidity and profitability and suggested maintaining the equilibrium between liquidity and profitability keeping the moderate paying ability to enhance the goodwill of the business organization. Sodha (2020) observed a negative relationship between liquidity and profitability and explained that either firm's profitability is satisfactory or liquidity. Aminu (2012) advocated the optimum balance between profitability and liquidity for the smooth operation of the business activities. The extreme of the liquidity will be negative for the profitability as it blocks the funds which can be utilized in operational activities. Ehiedu (2014) also observed a positive relationship between liquidity and profitability and suggested a balance between liquidity and profitability for the business organization to achieve the ultimate goal of profitability. Nandi (2012) studied that the companies try to maintain an optimum level of liquidity to run the business activities to earn the maximum possible profit. Bhunia et al. (2011) explained that working capital management is very crucial to manage and suggested the trade-off between liquidity and profitability. The efficient management of current assets and current liabilities will lead the business to attain the goal of expected profit by making payments of their dues on time. Saleem et al. (2011) conducted a study on the impacts of liquidity ratios on profitability and analyzed the liquidity and profitability of gas companies in Pakistan. They 
found that profitability and liquidity both are the interrelated and optimum balance between profitability liquidity is expected. Al Nimer et al. (2015) studied the impact of liquidity on profitability in banks of Jordan and found that the liquidity of the banks significantly affects the return on assets (ROA). It refers to the quick liquidity of the banks that governs the profitability of the banks positively. Zygmunt (2013, March) conducted one case study of polish listed IT companies in Poland and found a positive relationship between profitability and ingredients of the cash conversion cycle. He observed lag between the liquidity management and profitability of the organization. Vijayakumar (2011) suggested that shortening the cash conversion period and delay in making payments will enhance profitability. But, he suggested that the optimum balance between the short term inflow and outflow of the cash in the business to get the expected profit without any paying ability obstacles. Safdar et al. (2016) suggested that the firms' profitability can be increased if the liquid assets of the business managed efficiently. Goldmann (2017) revealed the importance of managing the ingredients of the current assets and current liabilities on the profitability of the business organization. He found the positive impact of efficient management of liquidity on profitability in polish businesses in Poland. Saluja (2012) explained that the trade-off between liquidity and profitability is very important in all organizations. The current assets and current liabilities are to be managed to get the optimum profit. The polar extreme level of the current assets and current liabilities will affect the profitability negatively. Bolek et al. (2012) explored that the growth of the liquidity of the business organization negatively affects the profitability because some funds will be unnecessarily blocked in the current assets. There should not be excessive investment in the current assets only to get a high level of liquidity. Rehman et al. (2015) found in their study on 99 companies listed in Saudi stock exchange and concluded only positivity between the liquidity (current ratio) and return on total (return on assets). Further, he found the negative but insignificant relationship between super liquidity (quick ratio) and cash ratio of the companiesBibi et al. (2017) carried out a correlation and regression analysis to assess the relationship profitability and liquidity on merchandising and manufacturing firms listed in Karachi stock exchange and found that significant negative relationship between cash-gap and ROA while liquidity and profitability relationship was positive. Almazari (2013) studied the liquidity and profitability of the cement companies of Saudi Arabia and found that there should be a trade-off between the liquidity and profitability to achieve the optimum objectives of the firms. He, further, found that the size of the firm also affects the profitability of the companies. Trippner (2013) calculated the correlation between the proxies of liquidity and profitability and could not get the relationship to generalize or explain the normal relationship between liquidity and profitability. Madushanka et al. (2018) found the significant impact of liquidity on profitability in manufacturing firms of Sri Lanka.

Janjua et al. (2016) found a positive and significant relationship between profitability and liquidity in cement companies listed in the Pakistani stock exchange. The liquidity governs the profitability of the cement companies of Pakistan. Ajao et al. (2012) conducted a study of the relationship between liquidity management and profitability on manufacturing companies listed in the Nigerian Stock Exchange. They found that the Cash Flow Management, Cash Conversion Cycle positively affected the profitability and suggested that the efficient credit policy, tightening of cash conversion period and cash flow management will be favorable for the business organization for the profitability point of view. Bala et al. (2016) conducted a study on food and beverage companies listed in Nigeria and found a strong positive correlation between liquidity proxies, firm size, and profitability. But, the debtors of the business and cash conversion period found negatively related to return on assets. They suggested shortening of the cash collection period to enhance the profitability of the food and beverage companies of Nigeria. Alom (2018) found in their study that profitability, firm size, and long term debts have a long-run cointegration relationship with the liquidity of the firm. Bagchi (2013) carried out a study on Fast Moving Consumer Goods (FMCG) firms in India and found negativity between firms' liquidity and profitability. He explored that the size of the firm has a positive correlation with the profitability of the FMCG firms. Yameen et al. (2016) found an insignificant relationship between profitability and liquidity of the Steel Authority of India Limited (SAIL) in a period of ten years i.e. 2005 to 2010. In the study period, the profitability of the SAIL lowers due to the increased prices of the raw materials. The short-term solvency of the SAIL decreased due to some other factors. Raykov (2017) explained in their study that the liquidity decisions of the firm minimally affect the profitability and financial performance, ultimately. In the Bulgarian economy, there is a weak and negative correlation between manageable liquidity and the operational profitability of the firms. The liquidity of the firm is not directly governed by the capital gains of the firms in Bulgaria. Ismail (2016) found from their study that liquidity variables and the cash conversion cycle period significantly and positively correlated with the profitability of total resources. Further, he indicated that the high liquidity and longer cash conversion cycle governs the firms' performance positively and suggested the relaxed credit sales policies and adopting the favorable collection system for the debtors to enhance the number of the customers to improve the overall performance of the firms. Anand et al. (2015) found the positivity between SCM and firms' performance and indicated that the inventory management, warehousing, growth of transport industry, advancements in information technology are the considerable aspects. Gunasekaran et al. (2004) advised that the SCM performance is necessary for the companies who are in a growing stage or facing competition. Ali (2021) revealed that the size of the business organization governs the SCF positively but not proportionately and suggested the shortening of the Cash Conversion cycle (CCC) focusing on accounts payable which is the major ingredients of the Working Capital (WC). From the above all studies it is obvious that the relationship between liquidity and profitability varies industry to industry and firm to firm. Some studies reveal the positive and significant relationship between profitability and liquidity while others reveal no relation or negative relation between profitability and liquidity. There is no clear pattern of relationship between profitability and liquidity is seen in previous studies. 


\section{Research methodology}

The study is purely based on secondary data extracted from financial statements available on the websites of the Indian pharmaceutical companies. Cipla Limited (CI), Cadila Healthcare Limited (CA), Sun Pharmaceutical Industries Limited (SU), Aurobindo Pharma Limited (AR), Dr. Reddy's Laboratories (DR), Glenmark Pharma Limited (GL), and Lupin limited (LU) pharmaceutical companies selected for the study of impact of supply chain performance on liquidity and profitability. Profitability ratio, Earning before Interest, Depreciation, and tax (EBIDT), Profit Before tax (PBT), and Profit After Tax (PAT), and liquidity ratio i.e. Current Ratio (CR) is the base of the analysis of financial data (Ali \& Haque, 2014).
1. EBIDT to Sales ratio $=\frac{\text { EBIDT }}{\text { Sales }} 100$;
2. PBT ratio $=\frac{P B T}{\text { Total resources }} 100$;
3. PAT ratio

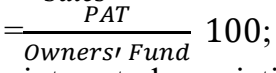
4. Current Ratio $(\mathrm{CR}) \%=\frac{C A}{C L} 100$;

Where, EBIDT=earnings before interest, depreciation, and tax; $\mathrm{PBT}=$ profit before tax; $\mathrm{PAT}=$ profit after tax; $\mathrm{CA}=\mathrm{current}$ assets; $\mathrm{CL}=$ current liabilities.

To know the productivity of the liquidity in the context profitability ratios, the following formula is to be applied:

Profitability to Current Ratio ( $\mathrm{P}_{\mathrm{EBIDT} / \mathrm{PBT} / \mathrm{PAT}}$ to $\left.\mathrm{CR}\right)=\frac{\text { Profitability Ratio }}{C R \text { in } \%} 100$;

Karl Pearson's correlation coefficient is calculated to get the relationship between the profitability ratios and CR. The relational correlation (Spearman's correlation coefficient) is to be calculated in between r (R1) of profitability ratios and CR and the relational productivity of the liquidity ( $\mathrm{P}$ to $\mathrm{CR}-\mathrm{R} 2)$ to explain the co-movement and sensitivity, mutually.

Spearman's Rank Correlation $\left(\mathrm{r}_{\mathrm{s}}\right)=1-\frac{6 * \sum(D * D)}{n(n * n-1)}$;

The cash conversion cycle (CCC) calculated to know the supply chain performance efficiency (Bui, 2020b) or operational velocity of the Indian pharmaceutical companies.

$\mathrm{CCC}=$ Inventory Days + Accounts Receivable Days - Accounts Payable Days;

Where,

Inventory days $=\frac{365 * A v . \text { Inventory }}{\text { COGS or Net Sales }} ; \quad$ Account Receivable days $=\frac{365 * A v . \text { Account Receivables }}{\text { Credit Sales or Net Sales }}$

Account Payable days $=\frac{365 * A v . \text { Account payables }}{\text { COGS or Net Sales }}$

(Note: In above formula, Net sales can be used in place of COGS while COGS is Cost Of Goods Sold.

\section{Analysis, Interpretation and results}

The analysis of Supply Chain Performance (SCP) and its impact on liquidity and profitability can be divided into two categories i.e. Relative SCP analysis, and Liquidity and profitability relationship of the Indian pharmaceutical companies.

\subsection{Relative Supply Chain performance analyses}

The SCP of the company refers the velocity in cash conversion cycle (CCC) or sharpness of the operational activities to investment of cash and getting it again after completing the operational cycle of the business activities.

The supply chain performance can be measured after consider the three ingredients of the CCC i.e. Inventory days, accounts receivables days, and accounts payable days.

\subsubsection{Inventory velocity or days}

Inventory days refer to the average number of days required to convert the raw material into finished products. The lesser inventory days reflect the velocity or sharpness of the manufacturing activities of the organization and stronger SCP. From the above table 1, it can be explained that the manufacturing velocity of the CA, LU, SU and CI is better than the AR, DR, and GL comparatively. It refers to the manufacturing and selling efficiency and unavailability of the negative factors in manufacturing and selling in the CA, LU, SU and CI pharmaceutical companies. 
Table 1

Inventory days in Indian Pharmaceuticals Companies (2013-18)

\begin{tabular}{|c|c|c|c|c|c|c|c|}
\hline Years & DR & LU & $\mathrm{SU}$ & $\mathrm{CI}$ & $\mathrm{AR}$ & $\mathrm{CA}$ & GL \\
\hline 2013 & 134 & 73 & 81 & 102 & 119 & 69 & 212 \\
\hline 2014 & 152 & 68 & 69 & 101 & 106 & 69 & 235 \\
\hline 2015 & 145 & 70 & 74 & 120 & 108 & 64 & 218 \\
\hline 2016 & 149 & 83 & 81 & 99 & 106 & 53 & 183 \\
\hline 2017 & 160 & 76 & 77 & 86 & 104 & 68 & 238 \\
\hline 2018 & 154 & 83 & 92 & 88 & 129 & 72 & 205 \\
\hline Av. & 149 & 75 & 79 & 99 & 112 & 66 & 215 \\
\hline Ranks & 6 & 2 & 3 & 4 & 5 & 1 & 7 \\
\hline
\end{tabular}

Source: Inventory days calculated from the data from the financial statement available on the websites of the concerned companies

\subsubsection{Account Receivables velocity or days}

Account receivables velocity or days refers the period of collection the cash from the debtors. The lesser period reflects the strong recovery policy and strategy of the organization and stronger SCP.

Table 2

Accounts Receivables days in Indian Pharmaceuticals Companies (2013-18)

\begin{tabular}{|c|c|c|c|c|c|c|c|}
\hline Years & DR & $\mathrm{LU}$ & $\mathrm{SU}$ & $\mathrm{CI}$ & AR & $\mathrm{CA}$ & GL \\
\hline 2013 & 90 & 82 & 75 & 72 & 99 & 55 & 119 \\
\hline 2014 & 86 & 78 & 48 & 57 & 118 & 57 & 131 \\
\hline 2015 & 95 & 74 & 67 & 64 & 83 & 67 & 140 \\
\hline 2016 & 99 & 115 & 86 & 61 & 80 & 62 & 120 \\
\hline 2017 & 96 & 89 & 82 & 61 & 66 & 86 & 95 \\
\hline 2018 & 102 & 119 & 104 & 67 & 68 & 97 & 93 \\
\hline Av & 95 & 93 & 77 & 64 & 86 & 70 & 116 \\
\hline Rank & 6 & 5 & 3 & 1 & 4 & 2 & 7 \\
\hline
\end{tabular}

Source: Accounts' receivables days calculated from the data from the financial statement available on the websites of the concerned companies

From the above Table 2, it is obvious that the recovery policy and strategy of CI, CA, SU, and AR is comparatively better and stronger than the DR, LU, and GL. It also refers that the CI, CA, SU, and AR are efficient in collection from the debtors and there is a positive atmosphere of recovery from the debtors in the normal course of business activities.

\subsubsection{Account payables velocity or days}

Account payables velocity or days refer the average number of days to make payment to the creditors in normal course of business activities. The maximum amount of inventory days reflects the positive payment strategy or policy of the business organization and stronger SCP.

Table 3

Accounts Payables days in Indian Pharmaceuticals Companies (2013-18)

\begin{tabular}{|c|c|c|c|c|c|c|c|}
\hline Years & DR & LU & $\mathrm{SU}$ & $\mathrm{CI}$ & AR & $\mathrm{CA}$ & GL \\
\hline 2013 & 70 & 84 & 33 & 36 & 60 & 37 & 75 \\
\hline 2014 & 50 & 73 & 29 & 34 & 61 & 46 & 83 \\
\hline 2015 & 42 & 94 & 43 & 50 & 61 & 46 & 108 \\
\hline 2016 & 55 & 99 & 44 & 38 & 66 & 49 & 93 \\
\hline 2017 & 51 & 98 & 50 & 39 & 52 & 58 & 69 \\
\hline 2018 & 62 & 120 & 64 & 46 & 58 & 57 & 74 \\
\hline Av. & 55 & 95 & 44 & 40 & 59 & 49 & 84 \\
\hline Ranks & 4 & 1 & 6 & 7 & 3 & 5 & 2 \\
\hline
\end{tabular}

Source: Accounts' receivables days calculated from the data from the financial statement available on the websites of the concerned companies

From the Table 3, it can be explained that the payment strategy of LU, GL, AR, and DR is comparatively better than the CA, SU, and CI in Indian pharmaceutical sector. LU, GL, AR, and DR companies enjoy the extended credit policies by their suppliers.

\subsubsection{Supply chain performance (SCP) and ranks of companies}

The SCP is the aggregative performance of the positivity of the manufacturing velocity, recovery from debtors' velocity and payment strategy or available credit facility by the suppliers. To know the supply chain performance of the business 
organization, the average of inventory days and recovery from the debtors' days added while average payment days to creditors are subtracted to get the SCP in form of CCC days.

\section{Table 4}

Average Cash conversion cycle of Indian pharmaceutical companies (2013-18)

\begin{tabular}{|c|c|c|c|c|c|c|c|}
\hline Days & DR & $\mathrm{LU}$ & $\mathrm{SU}$ & $\mathrm{CI}$ & $\mathrm{AR}$ & $\mathrm{CA}$ & GL \\
\hline Inventory Days & 149 & 75 & 79 & 99 & 112 & 66 & 215 \\
\hline Account receivable Days & 95 & 93 & 77 & 64 & 86 & 70 & 116 \\
\hline Account payable days & 55 & 95 & 44 & 40 & 59 & 49 & 84 \\
\hline Cash Conversion cycle days & 189 & 73 & 112 & 123 & 139 & 87 & 247 \\
\hline Ranks & 6 & 1 & 3 & 4 & 5 & 2 & 7 \\
\hline
\end{tabular}

Source: Based on calculation of table 1,2, and 3

From Table 4, it can be explained that the SCP of the LU, SU, CA, and CI is better than the DR, AR, and GL pharmaceutical companies of India. It reveals that the aggregative manufacturing velocity, recovery policies and strategies, and payment policy and credit availability by the suppliers is favorable in LU, SU, CA, and CI while weaker in DR, AR, and GL in Indian pharmaceutical companies.

\subsection{Liquidity and profitability analysis}

The mutual relationship of the liquidity and profitability can be explained among the three categories i.e. liquidity and gross profitability or gross earning (EBIDT), liquidity and profitability for total investment point of view (PBT), and liquidity and profitability for owners' point of view (PAT).

\subsubsection{Liquidity (CR) and gross profitability or gross earning (EBIDT)}

The relationship between liquidity (CR) and gross profitability or gross earning (EBIDT) measures the impact of the liquidity on gross profitability. The relationship between liquidity and gross profitability will reveal the utilization of liquidity to earn gross earnings.

The higher P to CR indicates that the business is managing its manufacturing activities efficiently in the liquidity context. The correlation and relational study explain the governance and impact of the liquidity position on profitability or utilization of the liquidity in the gross profit earning of the companies.

\section{Table 5}

Relationship and co-movement of EBIDT and Liquidity (CR) of Indian pharmaceutical companies

\begin{tabular}{|c|c|c|c|c|c|c|c|c|c|c|c|c|c|c|c|c|c|c|c|c|c|}
\hline \multirow[b]{2}{*}{ 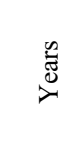 } & \multicolumn{3}{|c|}{ DR } & \multicolumn{3}{|c|}{ LU } & \multicolumn{3}{|c|}{ SU } & \multicolumn{3}{|c|}{$\mathrm{CI}$} & \multicolumn{3}{|c|}{ AR } & \multicolumn{3}{|c|}{$\mathrm{CA}$} & \multicolumn{3}{|c|}{ GL } \\
\hline & 官 & $\widetilde{\sim}$ & $\begin{array}{l}\stackrel{00}{0} \\
0 \\
0 \\
0\end{array}$ & 占 & $\stackrel{\alpha}{0}$ & $\begin{array}{l}\stackrel{0}{2} \\
\stackrel{0}{0} \\
\stackrel{0}{0}\end{array}$ & 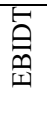 & $\widetilde{v}$ & 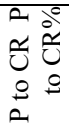 & 氙 & 䎹 & 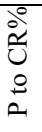 & 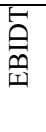 & $\stackrel{\sim}{\circlearrowright}$ & 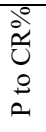 & 占 & 兄 & $\begin{array}{l}\stackrel{0}{0} \\
0 \\
\stackrel{0}{0} \\
0\end{array}$ & 氮 & $\widetilde{v}$ & $\begin{array}{l}\stackrel{0}{0} \\
\stackrel{0}{0} \\
0 \\
0\end{array}$ \\
\hline 2013 & 24 & 151 & 16 & 24 & 242 & 10 & 45 & 405 & 11 & 28 & 303 & 9 & 15 & 121 & 13 & 18 & 120 & 15 & 20 & 169 & 12 \\
\hline 2014 & 25 & 178 & 14 & 27 & 276 & 10 & 45 & 312 & 15 & 23 & 221 & 10 & 27 & 133 & 20 & 17 & 123 & 14 & 18 & 161 & 11 \\
\hline 2015 & 25 & 174 & 14 & 29 & 237 & 12 & 30 & 179 & 17 & 20 & 195 & 10 & 22 & 135 & 16 & 21 & 129 & 16 & 19 & 141 & 13 \\
\hline 2016 & 26 & 173 & 15 & 27 & 264 & 10 & 31 & 233 & 13 & 19 & 114 & 17 & 24 & 134 & 18 & 25 & 130 & 19 & 19 & 145 & 13 \\
\hline 2017 & 19 & 115 & 16 & 26 & 267 & 10 & 33 & 184 & 18 & 18 & 264 & 7 & 23 & 139 & 17 & 21 & 114 & 18 & 22 & 254 & 9 \\
\hline 2018 & 17 & 152 & 11 & 21 & 238 & 9 & 24 & 159 & 15 & 19 & 282 & 7 & 23 & 140 & 17 & 25 & 135 & 18 & 19 & 213 & 9 \\
\hline Av. & 23 & 157 & 14 & 26 & 254 & 10 & 35 & 245 & 14 & 21 & 230 & 9 & 22 & 134 & 16 & 21 & 125 & 17 & 20 & 181 & 11 \\
\hline$r$ & & 0.74 & & & 0.33 & & & 0.9 & & & 0.41 & & & 0.77 & & & 0.64 & & & 0.7 & \\
\hline $\mathrm{R} 1$ & & 3.5 & & & 6 & & & 3.5 & & & 7 & & & 2 & & & 1 & & & 5 & \\
\hline $\mathrm{R} 2$ & & 3 & & & 7 & & & 1 & & & 6 & & & 2 & & & 5 & & & 4 & \\
\hline D & & 0.5 & & & -1 & & & 2.5 & & & 1 & & & 0 & & & -4 & & & 1 & \\
\hline $\mathrm{D}^{2}$ & & 0.25 & & & 1 & & & 6.25 & & & 1 & & & 0 & & & 16 & & & 1 & \\
\hline
\end{tabular}

Source: EBIDT and CR ratios are calculated from the financial statements of the companies available on websites while R1 and R2 is ranks of $\mathrm{r}$ and ranks EBIDT and CR ratio, D is the difference of $\mathrm{R} 1$ and $\mathrm{D} 2$.

Spearman's Rank Correlation $\left(\mathrm{r}_{\mathrm{s}}\right)=1-\frac{6 * \sum(D * D)}{n(n * n-1)}, \quad=1-\frac{6 * 25.50}{7(7 * 7-1)} ; \quad=0.45$

The rank correlation of selected Indian pharmaceuticals reveals that there is a moderate correlation ( $\left.\mathrm{r}_{\mathrm{s}}=0.51\right)$ between utilization of the liquidity for profitability on owners' funds and the co-movement of the liquidity and profitability on owners' funds and 
A. Ali /Accounting 7 (2021)

liquidity (CR). It explains that the liquidity of the Indian pharmaceutical companies affects the profitability of owners' capital positively but not so strongly. In individual observation, it is found that some companies with higher utilization of the liquidity on owners' fund (AR-18\%, and DR-12\%) having a stronger correlation between the PAT and CR (AR-0.59, and DR-0.65) while some companies have a negative trend in between utilization of the liquidity for profitability on owners' fund and the comovement of the profitability on owners' fund (PAT) and liquidity (CR) i.e CA (16\%, $\left.\mathrm{r}_{\mathrm{s}}-0.22\right)$, and GL (9\%, $\left.\mathrm{r}_{\mathrm{s}}-0.34\right)$. The individual $\mathrm{P}_{\mathrm{PAT}}$ to $\mathrm{CR}$ ratio explains that CA (18\%), DR (12\%), and AR (18\%) pharmaceutical companies manage their Taxes, selling \& distribution, and administrative expenses including manufacturing expenses effectively.

So, it can be concluded that the Indian pharmaceutical companies utilizing liquidity and enjoying higher gross profitability, much sensitive and strong correlation between gross profitability (EBIDT) and liquidity (CR).

\subsubsection{Liquidity (CR) and profitability on total resources (PBT)}

The relationship between liquidity (CR) and profitability for the total investment point of view (PBT) measures the impact of the liquidity on the utilization of resources. The relationship between liquidity and profitability on total resources will reveal the utilization of liquidity to earn the profits on total investment in the business organization.

The higher P to CR indicates that the business is managing its selling \& distribution, and administrative expenses including manufacturing activities efficiently in the liquidity context. The correlation and relational study explain the governance and impact of liquidity on the profitability of utilization of the total assets or resources of the companies.

\section{Table 6}

Relationship and co-movement of PBT and Liquidity (CR) of Indian pharmaceutical companies

\begin{tabular}{|c|c|c|c|c|c|c|c|c|c|c|c|c|c|c|c|c|c|c|c|c|c|}
\hline \multirow[b]{2}{*}{$\begin{array}{l}\stackrel{\omega}{\vec{J}} \\
\dot{\nu}\end{array}$} & \multicolumn{3}{|c|}{ DR } & \multicolumn{3}{|c|}{ LU } & \multicolumn{3}{|c|}{ SU } & \multicolumn{3}{|c|}{ CI } & \multicolumn{3}{|c|}{$\mathrm{AR}$} & \multicolumn{3}{|c|}{ CA } & \multicolumn{3}{|c|}{ GL } \\
\hline & $\stackrel{n}{a}$ & ૈ & 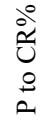 & $\stackrel{n}{a}$ & 어 & 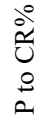 & $\stackrel{\vec{n}}{a}$ & 저 & $\begin{array}{l}\stackrel{0}{0} \\
0 \\
\stackrel{0}{0} \\
\text { a }\end{array}$ & $\stackrel{\underline{a}}{a}$ & $\approx ્ 04$ & $\begin{array}{l}\stackrel{0}{0} \\
\stackrel{0}{0} \\
\stackrel{0}{a} \\
\text { a }\end{array}$ & $\stackrel{n}{a}$ & 음 & $\begin{array}{l}\stackrel{0}{\circ} \\
\stackrel{0}{0} \\
\stackrel{0}{2}\end{array}$ & $\stackrel{n}{2}$ & 어 & 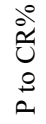 & $\stackrel{\mathfrak{m}}{\underline{2}}$ & 음 & $\begin{array}{l}\stackrel{0}{0} \\
0 \\
0 \\
0\end{array}$ \\
\hline 2013 & 16 & 151 & 11 & 22 & 242 & 9 & 24 & 405 & 6 & 18 & 303 & 6 & 5 & 121 & 4 & 11 & 120 & 9 & 10 & 169 & 6 \\
\hline 2014 & 17 & 178 & 9 & 28 & 276 & 10 & 24 & 312 & 8 & 14 & 221 & 6 & 16 & 133 & 12 & 12 & 123 & 10 & 8 & 161 & 5 \\
\hline 2015 & 16 & 174 & 9 & 26 & 237 & 11 & 14 & 179 & 8 & 11 & 195 & 5 & 17 & 135 & 12 & 16 & 129 & 13 & 9 & 141 & 6 \\
\hline 2016 & 13 & 173 & 8 & 15 & 264 & 6 & 14 & 233 & 6 & 8 & 114 & 7 & 17 & 134 & 13 & 21 & 130 & 16 & 10 & 145 & 7 \\
\hline 2017 & 7 & 115 & 6 & 13 & 267 & 5 & 15 & 184 & 8 & 6 & 264 & 2 & 19 & 139 & 13 & 11 & 114 & 9 & 13 & 254 & 5 \\
\hline 2018 & 6 & 152 & 4 & 8 & 238 & 3 & 7 & 159 & 4 & 8 & 282 & 3 & 15 & 140 & 11 & 13 & 135 & 10 & 9 & 213 & 4 \\
\hline Av. & 12 & 157 & 8 & 18 & 254 & 7 & 16 & 245 & 7 & 11 & 230 & 5 & 15 & 134 & 6 & 14 & 125 & 11 & 10 & 181 & 6 \\
\hline $\mathrm{r}$ & \multicolumn{3}{|c|}{0.69} & \multicolumn{3}{|c|}{0.16} & \multicolumn{2}{|c|}{0.89} & & \multicolumn{2}{|c|}{0.29} & & \multicolumn{2}{|c|}{0.89} & & \multicolumn{2}{|c|}{0.59} & \multicolumn{4}{|c|}{0.67} \\
\hline R1 & & 3 & & & 7 & & & 1.5 & & & 6 & & & 1.5 & & & 5 & & & 4 & \\
\hline $\mathrm{R} 2$ & & 2 & & & 3.5 & & & 3.5 & & & 7 & & & 5.5 & & & 1 & & & 5.5 & \\
\hline D & & 1 & & & 3.5 & & & -2 & & & -1 & & & -4 & & & 4 & & & -1.5 & \\
\hline $\mathrm{D}^{2}$ & & 1 & & & 12.25 & & & 4 & & & 1 & & & 16 & & & 16 & & & 2.25 & \\
\hline
\end{tabular}

Source: PBT and CR ratios are calculated from the financial statements of the companies available on websites while R1 and R2 is ranks of $\mathrm{r}$ and ranks EBIDT and CR ratio, D is the difference of $\mathrm{R} 1$ and $\mathrm{D} 2$.

Spearman's Rank Correlation $\left(\mathrm{r}_{\mathrm{s}}\right)=1-\frac{6 * \sum(D * D)}{n(n * n-1)}, \quad=1-\frac{6 * 52.50}{7(7 * 7-1)} ; \quad=0.06$

The rank correlation of selected Indian pharmaceutical reveals that there is a very low or negligible correlation $\left(\mathrm{r}_{\mathrm{s}}=0.06\right)$ between utilization of the liquidity for profitability on total investment and the co-movement of the profitability on total investment (PBT) and liquidity (CR). It explains that the liquidity of the Indian pharmaceutical companies does not affect profitability. In individual observation, it is found that some companies with higher utilization of the liquidity (DR-8\%, AR-6\%, and SU-7\%) for profitability on total investment are also having a stronger correlation between the PBT and CR (AR-0.89, SU-0.89, and DR-0.69) while some companies have a negative trend in between utilization of the liquidity for profitability on total investment and the co-movement of the profitability on total investment (PBT) and liquidity (CR) i.e CA (11\%, $\left.\mathrm{r}_{\mathrm{s}^{-}} 0.59\right)$, and LU (7\%, $\mathrm{r}_{\mathrm{s}}-$ 0.16). The individual $\mathrm{P}_{\mathrm{PBT}}$ to $\mathrm{CR}$ ratio explains that $\mathrm{CA}(11 \%), \mathrm{LU}(7 \%), \mathrm{SU}(7 \%)$, and $\mathrm{DR}(8 \%)$ pharmaceutical companies managing their selling \& distribution, and administrative expenses including manufacturing expenses effectively.

So, it can be said that there is a clear pattern of relationship between utilization of the liquidity for profitability on total investment and the co-movement of the profitability on total investment (PBT) and liquidity (CR). The return on total resources (PBT) is not affected by the liquidity status of the companies in the Indian pharmaceutical sector. 


\subsubsection{Liquidity (CR) and profitability on owners' fund (PAT)}

The relationship between liquidity (CR) and profitability for owners' point of view (PAT) measures the impact of the liquidity on the owners' fund or investment. The relationship of liquidity and profitability on the owner's fund will reveal the utilization of liquidity in order to earn the profits on the owner's fund in the business organization. The higher P to CR indicates that the business is managing its taxes including selling \& distribution, administrative expenses, and manufacturing activities efficiently in the liquidity context. The correlation and relational study explain the governance and impact of the liquidity on the profitability of owners' funds or owners' investment in the companies.

Table 7

Relationship and co-movement of PAT and Liquidity (CR) of Indian pharmaceutical companies

\begin{tabular}{|c|c|c|c|c|c|c|c|c|c|c|c|c|c|c|c|c|c|c|c|c|c|}
\hline \multirow[b]{2}{*}{ 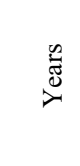 } & \multicolumn{3}{|c|}{ DR } & \multicolumn{3}{|c|}{ LU } & \multicolumn{3}{|c|}{ SU } & \multicolumn{3}{|c|}{ CI } & \multicolumn{3}{|c|}{$\mathrm{AR}$} & \multicolumn{3}{|c|}{$\mathrm{CA}$} & \multicolumn{3}{|c|}{ GL } \\
\hline & 导 & తิ & $\begin{array}{l}\stackrel{0}{0} \\
\text { حै } \\
\stackrel{0}{2} \\
\text { a }\end{array}$ & 芯 & 뜨 & 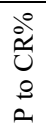 & 导 & ㄴ & 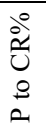 & 导 & తิ & $\begin{array}{l}\stackrel{0}{0} \\
\text { حै } \\
\stackrel{0}{0} \\
\stackrel{2}{2}\end{array}$ & 芯 & 뜨 & 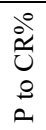 & 岕 & ิㅡ & 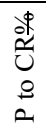 & 岕 & 으 & $\begin{array}{l}\stackrel{0}{0} \\
\stackrel{0}{0} \\
\stackrel{0}{0}\end{array}$ \\
\hline 2013 & 24 & 151 & 16 & 26 & 242 & 11 & 23 & 405 & 6 & 17 & 303 & 6 & 11 & 121 & 9 & 23 & 120 & 20 & 23 & 169 & 13 \\
\hline 2014 & 25 & 178 & 14 & 27 & 276 & 10 & 21 & 312 & 7 & 14 & 221 & 6 & 31 & 133 & 23 & 24 & 123 & 20 & 18 & 161 & 11 \\
\hline 2015 & 24 & 174 & 14 & 27 & 237 & 11 & 21 & 179 & 12 & 12 & 195 & 6 & 30 & 135 & 23 & 28 & 129 & 22 & 12 & 141 & 8 \\
\hline 2016 & 18 & 173 & 11 & 20 & 264 & 8 & 19 & 233 & 8 & 12 & 114 & 11 & 28 & 134 & 21 & 29 & 130 & 22 & 24 & 145 & 16 \\
\hline 2017 & 11 & 115 & 9 & 19 & 267 & 7 & 21 & 184 & 12 & 8 & 264 & 3 & 25 & 139 & 18 & 21 & 114 & 18 & 25 & 254 & 10 \\
\hline 2018 & 8 & 152 & 5 & 2 & 238 & 1 & 7 & 159 & 4 & 10 & 282 & 4 & 21 & 140 & 15 & 20 & 135 & 15 & 16 & 213 & 7 \\
\hline Av. & 18 & 157 & 12 & 20 & 254 & 8 & 19 & 245 & 8 & 12 & 230 & 5 & 24 & 134 & 18 & 20 & 125 & 16 & 16 & 181 & 9 \\
\hline $\mathrm{r}$ & & & & & & & & & & & & & & & & & & & & & \\
\hline $\mathrm{R} 1$ & & 1 & & & 5 & & & 3 & & & 7 & & & 2 & & & 6 & & & 4 & \\
\hline $\mathrm{R} 2$ & & 3 & & & 5.5 & & & 5.5 & & & 7 & & & 1 & & & 2 & & & 4 & \\
\hline D & & -2 & & & -0.5 & & & -2.5 & & & 0 & & & 1 & & & 4 & & & 0 & \\
\hline $\mathrm{D}^{2}$ & & 4 & & & 0.25 & & & 6.25 & & & 0 & & & 1 & & & 16 & & & 0 & \\
\hline
\end{tabular}

Source: PAT and CR ratios are calculated from the financial statements of the companies available on websites while R1 and R2 is ranks of $r$ and ranks EBIDT and CR ratio, D is the difference of $\mathrm{R} 1$ and $\mathrm{D} 2$.

Spearman's Rank Correlation $\left(\mathrm{r}_{\mathrm{s}}\right)=1-\frac{6 * \sum(D * D)}{n(n * n-1)}, \quad=1-\frac{6 * 27.50}{7(7 * 7-1)} ; \quad=0.51$

The rank correlation of selected Indian pharmaceuticals reveals that there is a moderate correlation $\left(\mathrm{r}_{\mathrm{s}}=0.51\right)$ between utilization of the liquidity for profitability on owners' funds and the co-movement of the liquidity and profitability on owners' funds and liquidity (CR). It explains that the liquidity of the Indian pharmaceutical companies affects the profitability of owners' capital positively but not so strongly. In individual observation, it is found that some companies with higher utilization of the liquidity on owners' fund (AR-18\%, and DR-12\%) having a stronger correlation between the PAT and CR (AR-0.59, and DR-0.65) while some companies have a negative trend in between utilization of the liquidity for profitability on owners' fund and the comovement of the profitability on owners' fund (PAT) and liquidity (CR) i.e CA (16\%, $\left.\mathrm{r}_{\mathrm{s}}-0.22\right)$, and GL (9\%, $\left.\mathrm{r}_{\mathrm{s}}-0.34\right)$. The individual $\mathrm{P}_{\mathrm{PAT}}$ to $\mathrm{CR}$ ratio explains that $\mathrm{CA}(18 \%)$, DR (12\%), and AR (18\%) pharmaceutical companies manage their Taxes, selling \& distribution, and administrative expenses including manufacturing expenses effectively. So, it can be said that there is a clear pattern of relationship between utilization of the liquidity for profitability on owners' funds and the co-movement of the profitability on owners' funds (PAT) and liquidity (CR). The return on owners' funds (PAT) is not strongly affected by the liquidity status of the companies in the Indian pharmaceutical sector.

\subsection{SCP, profitability and liquidity}

The comparative relationship between SCP, liquidity and profitability will reveal the coherence and governance of the SCP on the profitability and the liquidity of the business organization.

\subsubsection{SCP and profitability}

The SCP and profitability relative comparative study will reveal the relationship and impact of the SCP on the profitability of the business organization.

Spearman's Rank Correlation $\left(\mathrm{r}_{\mathrm{s}}\right)=1-\frac{6 * \sum(D * D)}{n(n * n-1)}, \quad=1-\frac{6 * 65.66}{7(7 * 7-1)} ; \quad=-0.17$

From Table 8, it is obvious that there is a weak but negative relationship between the average SCP and the profit earning capacity of the Indian pharmaceutical companies. The SCP may enhance the absolute amount of the profitability but there is no positive impact on the profitability of the Indian pharmaceutical companies. 
Table 8

Relative relationship between av. SCP and profitability

\begin{tabular}{|c|c|c|c|c|c|c|c|}
\hline Ranks & DR & $\mathrm{LU}$ & $\mathrm{SU}$ & $\mathrm{CI}$ & $\mathrm{AR}$ & $\mathrm{CA}$ & GL \\
\hline R1 (SCP) & 6 & 1 & 3 & 4 & 5 & 2 & 7 \\
\hline R2 (Profitability) & 2.5 & 6 & 2.67 & 6.67 & 1.83 & 4 & 4.33 \\
\hline $\mathrm{D}(\mathrm{R} 1-\mathrm{R} 2)$ & 3.5 & -5 & 0.33 & -2.67 & 3.17 & -2 & 2.67 \\
\hline $\mathrm{D}^{2}$ & 12.25 & 25 & 0.11 & 7.13 & 10.04 & 4 & 7.13 \\
\hline
\end{tabular}

Source: R1 is from table 4 while $\mathrm{R} 2$ is the av. of profitability ranks given in table 1, 2, and 3.

\subsubsection{SCP and liquidity}

The SCP and liquidity relative comparative study will reveal the relationship and impact of the SCP on the liquidity of the business organization.

Table 9

Relative relationship between av. SCP and profitability

\begin{tabular}{|c|c|c|c|c|c|c|c|}
\hline Ranks & DR & $\mathrm{LU}$ & SU & $\mathrm{CI}$ & $\mathrm{AR}$ & $\mathrm{CA}$ & GL \\
\hline R1 (SCP) & 6 & 1 & 3 & 4 & 5 & 2 & 7 \\
\hline R2 (Liquidity) & 2.67 & 5.33 & 3.33 & 6.67 & 2.83 & 2.67 & 4.5 \\
\hline $\mathrm{D}$ (R1-R2) & 3.33 & -4.33 & 0.33 & -2.67 & 2.17 & 0.67 & 2.5 \\
\hline $\mathrm{D}^{2}$ & 11.09 & 18.75 & 0.11 & 7.13 & 4.71 & 0.45 & 6.25 \\
\hline
\end{tabular}

Source: R1 is from table 4 while R2 is the av. of liquidity ranks given in table 1,2 , and 3 .

Spearman's Rank Correlation $\left(\mathrm{r}_{\mathrm{s}}\right)=1-\frac{6 * \sum(D * D)}{n(n * n-1)}, \quad=1-\frac{6 * 48.49}{7(7 * 7-1)} ; \quad=0.13$

From the table 9, it is obvious that there is weak but positive relationship between the average SCP and the liquidity of the Indian pharmaceutical companies. The SCP may enhance the short term paying capacity of the business organization negligibly but there is no strong and positive impact on the liquidity of the Indian pharmaceutical companies.

\section{Discussion of Findings}

There is a positive and moderate relationship between liquidity and gross earning or gross profitability, and profitability on owners' funds while there is a negligible relationship between liquidity and profitability on total resources in the Indian pharmaceutical sector. The Indian pharmaceutical companies utilizing liquidity and enjoying higher gross profitability that are much sensitive and strong correlation between gross profitability (EBIDT) and liquidity (CR). There is a positive relationship between liquidity and profitability in Indian pharmaceutical industries (Yameen, Farhan, \& Tabash, 2019; Viswanathan, Palanisamy, \& Mahesh, 2016). But, there is a clear pattern of relationship between the utilization of the liquidity for profitability on total investment and the co-movement of the profitability on total investment (PBT) and liquidity (CR). Also, there is a similar and a clear pattern of relationship between utilization of the liquidity for profitability on owners' funds and the co-movement of the profitability on owners' funds (PAT) and liquidity (CR). The return on total resources (PBT) and owner's fund (PAT) is not strongly affected by the liquidity status of the companies in the Indian pharmaceutical sector. There is a negative relationship between profitability and liquidity in the Indian pharmaceutical industries (Priya \& Nimalathasan, 2013; Panigrahi et al., 2018; Pushparaj Kulkarni, \& Pimplapure, 2019; Johny, 2017). The relationship between SCP and profitability is weak and negative while SCP and liquidity are weak but positive. SCP may enhance the absolute amounts of profits due to operational efficiency or velocity but not the profit earning capacity of the Indian pharmaceutical companies. SCP negligibly improves the short term paying ability of Indian pharmaceutical companies.

\section{Conclusion}

\subsection{Results}

Based on the above analysis and results, interpretations, and discussions it can be concluded that there is a positive and moderate correlation between liquidity and gross profitability and profitability on owners' funds. The liquidity and profitability's relationship is satisfactory when compared with the sales turnover and owners' fund while profitability and liquidity ratio is low when compared with total resources. It refers to either the interest and depreciation amounts are heavy or there is heavy investment in total resources or both. The sensitivity can be seen in the Indian pharmaceutical companies utilizing liquidity and enjoying higher gross profitability while low sensitivity in the companies enjoying low gross profitability, proportionately. 
There is a low sensitivity of liquidity and profitability on total resources and profitability on owners' funds. The higher utilization of liquidity does not govern the total resources' profitability and owners' profitability. It is revealed in the previous studies there is a negative relationship between liquidity and profitability. The SCP negligibly affects the profitability and liquidity of the Indian pharmaceutical companies positively and negatively, respectively. The velocity of the operational efficiency decreases the profit earning capacity but may enhance the absolute amounts of profit while improving the short term paying ability negligibly.

\subsection{Limitations}

The study considers only limited period data from 2013 to 2018 for the study of the relationship of SCP, profitability, and liquidity, or short-term paying ability. There should be consideration of Inflow and outflow of the cash for the study period to get the exact items of cash expenditures and revenues. Analysis of the SCP in the study will be minutely different because the amount of net sales is to be used in place of COGS. There is scope for further research to consider the comparative analysis of all ingredients of current assets and current liabilities, manufacturing, and selling and distribution of Indian pharmaceutical companies for a period more than 10 years to get a clear trend of the relationship of profitability and liquidity.

\subsection{Managerial implications}

So, after considering the SCP, liquidity, all profitability (EBIDT, PBT, and PAT), and sensitivity of movement of the profitability to $\mathrm{CR}$ and relational profitability, it can be concluded that optimum balance should be maintained to run uninterrupted business activities. There is no strong relationship or impact of the SCP that governs profitability and liquidity negligibly. But, the sharpening of the SCP will enhance the absolute amounts of the profits and improve the short- term liquidity also. The relationship between liquidity and profitability and relational sensitivity is not very directional about profitability on total resources and owners' funds (Aminu, 2012; Ehiedu, 2014; Bhunia et al., 2011). There should be an improvement in the profitability of a positive impact on liquidity (Ben-Caleb et al., 2013).

\section{Acknowledgement}

The author would like thank to Deanship of scientific research, Prince Sattam Bin Abdulaziz University, Saudi Arabia.

\section{References}

Ajao, S., \& Small, S. (2012). Liquidity management and corporate profitability: Case study of selected manufacturing companies listed on the Nigerian stock exchange. Business Management Dynamics, 2(2), 1-10.

Al Nimer, M., Warrad, L., \& Al Omari, R. (2015). The impact of liquidity on Jordanian banks profitability through return on assets. European Journal of Business and Management, 7(7), 229-232.

Alagathurai, A. (2013). A nexus between liquidity \& profitability: a study of trading companies in Sri Lanka.

Ali, A. (2021). Firm size and supply chain finance in Indian pharmaceutical industry: Relational firm analysis of size determinants and cash conversion cycle. Accounting, 7(1), 197-206.

Ali. A. (2020a). Do the giant players enjoy profitability? : Analytical study of Pharmaceutical Industry of India. Talent Development \& Excellence, 12(2s), 3249-3260.

Ali. A.(2020b). Does Size Affect Financial Performance? : Absolute and Relative Analysis of Materials Sector Companies of Saudi Arabia. Journal of Critical Reviews, 7(15), 212-220.

Ali. A., Haque, M.I. (2014). Ratio Analysis: A Comparative Study of National Petrochemicals Co. and Sahara Petrochemicals Co. of Saudi Arabia. International Journal of Management Academy, 2(4), 53-61.

Almazari, A. A. (2013). The relationship between working capital management and profitability: Evidence from Saudi cement companies. British Journal of Economics, Management \& Trade, 4(1), 146-157.

Alom, K. (2018). Liquidity and Profitability: A Co-Integration Study. Review of Pacific Basin Financial Markets and Policies, 21(02), 1850011-20.

Aminu, Y. (2012). A nexus between liquidity/profitability trade-offs for working capital management in Nigerias manufacturing sector. International Journal of Arts and Commerce, 1(6), 55-58.

Anand, N., \& Grover, N. (2015). Measuring retail supply chain performance. Benchmarking: An International Journal, 22 (1), 135-166. DOI 10.1108/BIJ-05-2012-0034

Bagchi, B. (2013). Liquidity-profitability relationship: empirical evidence from Indian fast moving consumer goods firms. International Journal of Applied Management Science, 5(4), 355-376.

Bala, H., Garba, J., \& Ibrahim, I. (2016). Corporate liquidity and profitability of listed food and beverages firms in Nigeria. Net Journal of Social Sciences, 4(1), 10-22. 
Ben-Caleb, E., Olubukunola, U., \& Uwuigbe, U. (2013). Liquidity management and profitability of manufacturing companies in Nigeria. IOSR Journal of Business and Management, 9(1), 13-21.

Bhunia, A., Khan, I., \& MuKhuti, S. (2011). A study of managing liquidity. Journal of Management Research, 3(2), 1-22.

Bibi, N., \& Amjad, S. (2017). The relationship between liquidity and firms' profitability: A case study of Karachi Stock Exchange. Asian Journal of Finance \& Accounting, 9(1), 54-67.

Bolek, M., \& Wili'nski, W. (2012). The influence of liquidity on profitability of polish construction sector companies. EFinanse: Financial Internet Quarterly, 8(1), 38-52.

Bui, T. N. (2020). Supply chain finance, financial development and profitability of real estate firms in Vietnam. Uncertain Supply Chain Management, 8(1), 37-42.

Ehiedu, V. C. (2014). The impact of liquidity on profitability of some selected companies: The financial statement analysis (FSA) approach. Research Journal of Finance and Accounting, 5(5), 81-90.

Farhan, N. H., Alhomidi, E., Almaqtari, F. A., \& Tabash, M. I. (2019). Does Corporate Governance Moderate the Relationship between Liquidity Ratios and Financial Performance? Evidence from Indian Pharmaceutical Companies. Academic Journal of Interdisciplinary Studies, 8(3), 144-144.

Goldmann, K. (2017). Financial liquidity and profitability management in practice of polish business. In Financial Environment and Business Development (pp. 103-112). Springer, Cham.

Gunasekaran, A., Patel, C., \& McGaughey, R. E. (2004). A framework for supply chain performance measurement. International Journal of Production Economics, 87(3), 333-347.

Ismail, R. (2016). Impact of liquidity management on profitability of Pakistani firms: A case of KSE-100 Index. International Journal of Innovation and Applied Studies, 14(2), 304-314.

Janjua, A. R., Asghar, A., Munir, U., Raza, A., Akhtar, N., \& Shahzad, K. (2016). Influence of Liquidity on Profitability of Cement Sector: Indication from Firms Listed in Pakistan Stock Exchange. Business Management Dynamics, 6(5), 1-12.

Johnson, M., \& Templar, S. (2011). The relationships between supply chain and firm performance. International Journal of Physical Distribution \& Logistics Management, 41(2), 88-103. DOI 10.1108/09600031111118512

Kumar, S., Srivastava, P., Sinha, S. K., \& Goyal, R. (2016). A Study of Financial Efficiency and Liquidity Position of Indian Pharmaceutical Industry Special Reference to Cipla Ltd. International Journal of Innovations in Engineering and Technology, 7(1), 702-711.

Madushanka, K. H. I., \& Jathurika, M. (2018). The impact of liquidity ratios on profitability. International Research Journal of Advanced Engineering and Science, 3(4), 157-161.

Mohanty, B., \& Mehrotra, S. (2018). Relationship between Liquidity and Profitability: An Exploratory Study of SMEs in India. Emerging Economy Studies, 4(2), 169-181.

Nandi, K. C. (2012). Trends in liquidity management and their impact on profitability: a case study. Great Lakes Herald, 6(1), 16-30.

Panigrahi, C. M. A. (2019). Liquidity and Profitability Relationship and Financial Fallacy. Think India Journal, 22(10). 704718.

Panigrahi, C. M. A., Raul, N., \& Gijare, C. (2018). Liquidity and profitability trade-off: A study of Indian pharmaceutical companies. NMIMS Journal of Economics and Public Policy, 3(1). 42-56.

Priya, K., \& Nimalathasan, B. (2013). Liquidity management and profitability: A case study of listed manufacturing companies in Sri Lanka. International Journal of Technological Exploration and Learning, 2(4), 161-165.

Pushparaj Kulkarni, D., \& Pimplapure, V. (2019). An Analytical Study of Profitability of Pharmaceutical Companies in India. Journal of the Gujarat Research Society, 21(16), 50-57.

Raykov, E. (2017). The liquidity-profitability trade-off in Bulgaria in terms of the changed financial management functions during crisis. Management: journal of Contemporary Management Issues, 22(1), 135-156.

Rehman, M. Z., Khan, M. N., \& Khokhar, I. (2015). Investigating liquidity-profitability relationship: Evidence from companies listed in Saudi stock exchange (Tadawul). Journal of Applied Finance and Banking, 5(3), 159.

Safdar, M. Z., Awan, M. Z., Ahmed, Z., Qureshi, M. I., \& Hasnain, T. (2016). What does matter? Liquidity or profitability: A case of sugar industry in Pakistan. International Journal of Economics and Financial Issues, 6(3S).

Saleem, Q., \& Rehman, R. U. (2011). Impacts of liquidity ratios on profitability. Interdisciplinary Journal of Research in Business, 1(7), 95-98.

Saluja, P., \& Kumar, P. (2012). Liquidity and profitability trade-off. International Journal of Advanced Research in Management and Social Sciences, 1(3), 77-84.

Sinha, M. B., \& Singhavi, D. (2017). Liquidity \& profitability analysis of the pharmaceutical companies of India. CLEAR International Journal of Research in Commerce \& Management, 8(7). 97-99.

Sinha, S. K., Goyal, R., Kumar, S., \& Gupta, V. A (2016). Study on Engineering of Cash Management and its impact on Profitability of Indian Pharmaceutical Industry with Special Reference to Cipla Ltd. International Journal of Innovations in Engineering and Technology (IJIET),6(4), 469-478.

SODHA, S. (2020). A Comparison of Pharma Companies Based on Profitability and Liquidity. Tathapi Journal, 19(24), 157162. 
Srivastva, A. (2017).Diagnosing Inter Firm Profitability of Pharmaceutical Industry: An Empirical Analysis for India. IJCRR, 9(9), 32-36. DOI: http://dx.doi.org/10.7324/IJCRR.2017.993236

Trippner, P. (2013). Analysis of Financial Liquidity Management in the Enterprise and its Impact on the Profitability. In Proceedings of 14th International Conference on Finance and Banking. Karviná: Silesian University, School of Business Administration (pp. 494-501).

Vijayakumar, A. (2011). Management of corporate liquidity and profitability: an empirical study. International Journals of Marketing and Technology, 1(6), 156-175.

Yameen, M., \& Pervez, A. (2016). Impact of liquidity, solvency and efficiency on profitability of steel authority of India limited. International Journal of Accounting Research, 42(3968), 1-10.

Zygmunt, J. (2013, March). Does liquidity impact on profitability? In Conference of informatics and management sciences, March (pp. 38-49).

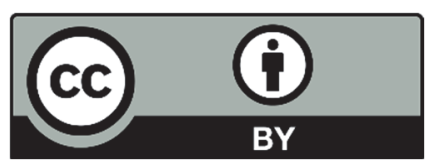

C 2021 by the authors; licensee Growing Science, Canada. This is an open access article distributed under the terms and conditions of the Creative Commons Attribution (CC-BY) license (http://creativecommons.org/licenses/by/4.0/). 